\title{
ANALISIS KEANDALAN DATA PENAKAR HUJAN OTOMATIS SEBAGAI ACUAN KOREKSI PERKIRAAN HUJAN RADAR
}

\author{
Roby Hambali $^{1}$, Djoko Legono ${ }^{2}$, Rachmad Jayadi $^{2}$ \\ ${ }^{1}$ Mahasiswa Program Doktor Teknik Sipil, Departemen Teknik Sipil dan Lingkungan, Fakultas Teknik \\ Universitas Gadjah Mada, Yogyakarta \\ ${ }^{2}$ Departemen Teknik Sipil dan Lingkungan, Fakultas Teknik Universitas Gadjah Mada, Yogyakarta \\ Koresponden email: roby.hambali@mail.ugm.ac.id
}

\begin{abstract}
Abstrak: Pengujian keandalan (reliability) data penakar hujan otomatis (ARR) di wilayah Gunung Merapi sangat diperlukan, mengingat data tersebut digunakan sebagai acuan untuk mengoreksi kesalahan perkiraan hujan radar X-band MP. Stasiun-stasiun ARR yang mengandung data tidak andal perlu dieliminasi agar perkiraan hujan radar dapat dikoreksi berdasarkan data yang benar. Makalah ini membahas tentang teknik analisis keandalan data penakar hujan menggunakan uji ragam dua arah. Metode uji ragam yang digunakan adalah metode Scheffe, dimana selisih nilai rata-rata dua stasiun ARR dibandingkan dengan nilai kritik uji Scheffe. Kriteria yang diangkat untuk menyatakan 'andal' adalah apabila jumlah stasiun yang memiliki perbedaan nyata dengan stasiun yang ditinjau kurang dari dua. Sebanyak 5939 data intensitas hujan 10 menitan dari 21 stasiun ARR di wilayah Gunung Merapi digunakan dalam analisis. Hasilnya menunjukkan bahwa enam dari 21 stasiun ARR mengandung data yang tidak andal digunakan sebagai acuan koreksi perkiraan hujan radar. Metode uji Scheffe cukup sederhana dan mudah diterapkan untuk mengetahui beda nyata nilai rata-rata antar stasiun ARR.
\end{abstract}

Kata Kunci: Penakar hujan otomatis, keandalan, uji Scheffe, Gunung Merapi

\begin{abstract}
The reliability test of automatic rain gauge data in the Mt. Merapi region is highly needed considering that the data is used as a reference to correct the X-band MP radar rainfall estimates error. Rain gauge stations containing unreliable data need to be eliminated so that radar rainfall estimates can be adjusted based on reliable data only. This paper discusses the technique of examining the reliability of rain gauge data using a two-way analysis of variance. The method used in variance analyzing is the Scheffe test, where the difference in the mean value of the two rain gauge stations is compared with the critical value of the Scheffe test. The criteria appointed to declare 'reliable' is if the number of stations that have a significant difference with the reviewed station is less than two. A total of 5939 10-minute rainfall intensity data from 21 rain gauge stations in the Mt. Merapi region were used in the analysis. The results show that six of the 21 rain gauge stations contain unreliable data to use as a reference for correcting radar rainfall estimates. The Scheffe test is considered excellent and straightforward to apply to find out the variance of mean values between rain gauge stations.
\end{abstract}

Keywords: Automatic rain gauge, reliability, Scheffe test, Mt. Merapi

Hujan merupakan faktor kunci pemicu aliran lahar di Wilayah Gunung Merapi. Informasi hujan yang dihasilkan dari proses pemantauan memberikan kontribusi yang signifikan bagi mitigasi bencana banjir lahar. Dewasa ini, pemantauan hujan menggunakan radar hujan dianggap lebih menguntungkan dibanding menggunakan penakar hujan. Radar hujan dapat melakukan perekaman dengan cakupan wilayah yang luas, distribusi data real time dengan resolusi spasial dan temporal yang tinggi. Sebaliknya, pengamatan hujan yang dilakukan melalui pengukuran langsung menggunakan penakar hujan menyediakan 
informasi spasial yang terbatas, khusunya untuk hujan konvektif atau pada daerah dengan topografi yang kompleks (Yoon dan Bae 2013; Burcea, dkk., 2012). Meskipun radar hujan memiliki keunggulan pada jangkauan spasialnya, namun hasil perkiraan hujan radar tidak cukup presisi dibandingkan dengan pengukuran kedalaman hujan menggunakan penakar hujan, karena dipengaruhi berbagai sumber kesalahan (Burcea, dkk., 2012; Rossa, dkk., 2010).

Pemenuhan kebutuhan akan data curah hujan yang andal (reliable) mungkin tidak terpenuhi hanya dengan menggunakan salah satu sumber data saja. Penggabungan semua sumber data yang memungkinkan seperti penakar hujan, radar, dan lain-lain dapat memberikan perkiraan curah hujan yang lebih baik (Tauro, dkk., 2018). Dalam hal penggunaan dan pengembangan teknologi radar hujan, alat penakar hujan otomatis masih tetap diperlukan sebagai acuan evaluasi ketepatan nilai perkiraan hujan radar. Secara sederhana, ketelitian perkiraan kedalaman hujan radar dievaluasi berdasarkan hujan permukaan dari penakar hujan (Hong dan Gourley, 2015). Sahlaoui dan Mordane (2019) menyatakan bahwa peningkatan kualitas perkiraan hujan radar berdasarkan data curah hujan permukaan tergantung pada kualitas data penakar hujan dan metode yang divalidasi dengan baik. Dalam analisis evaluasi kesesuaian data hujan radar terhadap hujan permukaan, asumsi dasar yang digunakan adalah data hujan permukaan dianggap memiliki kebenaran dasar (Sebastianelli, 2012). Namun demikian, penurunan kualitas data hujan permukaan dapat saja terjadi akibat penurunan kinerja penakar hujan yang disebabkan oleh berbagai faktor, misalnya usia pemakaian, gangguan serangga, kerusakan perangkat keras maupun perangkat lunak. Untuk itu, sebelum data penakar hujan digunakan sebagai acuan koreksi perkiraan hujan radar, evaluasi keandalan data penakar hujan itu sendiri perlu dilakukan.

Hingga saat ini belum ditemui metode yang spesifik digunakan untuk mengevaluasi keandalan (reliability) data penakar hujan untuk distribusi hujan durasi pendek (misal jam-jaman atau menitan). Mengingat hujan durasi pendek bersifat sesaat dan tidak kontinu, uji konsistensi (consistency test) seperti double mass curve yang biasa digunakan untuk evaluasi hujan durasi panjang sulit untuk diadopsi. Alternatif uji lain yang berpotensi untuk diterapkan adalah uji ragam (analysis of variance, ANOVA). Dengan mengasumsikan data pada satu stasiun penakar hujan merupakan bagian dari populasi data hujan seluruh stasiun dalam satu wilayah dengan karakteristik yang serupa, maka uji keragaman data dapat digunakan. Uji ragam adalah suatu metode uji untuk menguraikan keragaman total menjadi komponen-komponen yang mengukur berbagai sumber keragaman (Wibisono, 2015). Melalui uji ragam akan diketahui apakah terdapat perbedaan yang signifikan atau tidak dari beberapa rata-rata sampel yang diselidiki.

Makalah ini menyajikan teknik analisis keandalan data hujan permukaan yang berasal dari penakar hujan otomatis dengan menggunakan uji ragam. Dengan menerapkan uji ragam akan diketahui stasiun-stasiun penakar hujan mana saja yang memiliki data yang layak untuk digunakan sebagai acuan koreksi perkiraan hujan radar.

\section{BAHAN DAN METODE Penakar hujan otomatis}

Salah satu tipe penakar hujan otomatis yang paling banyak digunakan saat ini adalah tipping bucket (Nystuen, dkk., 1996; Rashid, dkk., 2015; Strangeways, 2010). Penakar hujan tipe tipping bucket banyak digunakan karena memiliki bentuk dan sistem yang sederhana, tahan lama, dapat dihubungkan dengan instrumen pemantau dan pencatat data yang lain, serta memiliki harga yang relatif murah (Muliantara, dkk., 2015). Namun demikian, perhatian serius perlu diberikan terhadap penggunaan penakar hujan otomatis, mengingat hasil pengukurannya tidak benarbenar tepat dengan hujan yang jatuh dipermukaan tanah. Hal tersebut, selain disebabkan keterbatasan ukuran dari penakar hujan, juga dapat disebabkan oleh kesalahan sistematis. Dalam WMO (2010) disebutkan beberapa sumber kesalahan dari penakar hujan tipe tipping bucket, antara lain kehilangan air selama aksi tipping dalam situasi hujan lebat, kehilangan air akibat penguapan, data yang kurang memuaskan akibat sifat rekaman yang terputus-putus, adanya residu pada bucket akibat pembasahan dinding dalam penakar, pembacaan yang berlebihan akibat aliran air yang jatuh dari corong ke bucket, serta kerentanan terhadap gesekan pada pivot dan memiliki bucket yang tidak seimbang karena ukurannya tidak rata. 
Kesalahan-kesalahan lain yang juga berpotensi terjadi secara umum untuk semua tipe penakar hujan antara lain kesalahan akibat deformasi sistematis dari bidang angin di atas orifice, kesalahan akibat percikan air yang masuk dan keluar penakar hujan, serta kesalahan acak pengamatan dan instrumentasi, termasuk waktu pembacaan penakar yang keliru. Kalibrasi yang baik dapat memberikan koreksi terhadap kesalahan sistematis yang terjadi (WMO, 2010). Namun demikian, beberapa kesalahan sistematis harus ditangani secara khusus. Penanganan yang dimaksud dapat berupa pemeliharaan rutin yang mencakup pembersihan kotoran dan serpihan yang terakumulasi pada corong dan bucket, pemeriksaan kerataan bucket, serta pemeriksaan interval waktu dan tanggal pencatatan. Selain itu, sangat disarankan agar perangkat tipping bucket dapat diganti dengan unit yang baru dikalibrasi setiap tahun.

Real Time Clock (RTC) offset pada instrumen penakar hujan merupakan salah satu jenis kesalahan yang paling sering ditemui pada jaringan pemantauan hujan di wilayah Gunung Merapi, dimana waktu yang terekam pada logger tidak sama dengan waktu aktual. Kesalahan tersebut terjadi akibat adanya kelemahan pada perangkat keras perekam (logger). RTC offset bersifat akumulatif, sehingga dapat bertambah atau berkurang seiring berjalannya waktu. Kesalahan ini dapat diperbaiki dengan melakukan pengaturan ulang pada perangkat router mikrotik, namun dapat terjadi kembali seiring dengan berjalannya waktu. Pemeriksaan secara rutin terhadap RTC offset sangat disarankan untuk meminimalisir terjadinya RTC offset. Untuk rekaman data yang mengandung $R T C$ offset disarankan untuk dilakukan koreksi waktu terlebih dahulu sebelum data hujan digunakan pada analisis yang lain.

\section{Uji ragam Scheffe}

Pada uji ragam, asumsi dasar yang harus dipenuhi adalah sampel acak yang dipilih harus berdistribusi normal, kecuali untuk sampel yang besar. Wibisono (2015) menyatakan perlu menguji validitas hipotesis nol dengan memanfaatkan seluruh data yang ada untuk mengetahui ada tidaknya perbedaan nilai ratarata sampel. Bentuk umum rumusan hipotesis nol dan hipotesis alternatif untuk pengujian dua arah ditunjukkan pada Persamaan (1).

$$
\left.\begin{array}{l}
H_{0}: \mu_{1}=\mu_{2}=\ldots=\mu_{r} \\
H_{a}: \mu_{1} \neq \mu_{2} \neq \ldots \neq \mu
\end{array}\right\}
$$

Hipotesis nol $\left(H_{0}\right)$ menyatakan bahwa beberapa nilai rata-rata sampel memiliki nilai parameter populasi yang sama, sedangkan hipotes alternatif $\left(H_{a}\right)$ menyatakan bahwa setidaknya ada nilai rata-rata sampel dari populasi tertentu memiliki rata-rata yang berbeda. Namun demikian, dengan penolakan hipotesis nol belum dapat diketahui nilai ratarata mana saja yang tidak sama. Untuk mengatasi masalah tersebut, dapat diterapkan uji perbandingan ganda. Salah satu uji perbandingan ganda untuk analsis ragam adalah metode Scheffe (McHugh, 2011). McHugh (2011) menyatakan bahwa metode ini lebih unggul daripada metode yang lain untuk pengujian ragam yang melibatkan semua ratarata sampel. Dalam metode Scheffe, selisih rata-rata dari dua buah sampel dengan taraf nyata $\alpha$ dapat dirumuskan sebagai berikut (Wibisono, 2015):

$$
\begin{aligned}
& \left(\mu_{1}-\mu_{2}\right)=\left(\bar{X}_{1}-\bar{X}_{2}\right) \pm \\
& \sqrt{(N-1) F_{\alpha}} s_{P} \sqrt{\frac{1}{n_{1}}+\frac{1}{n_{2}}}
\end{aligned}
$$

$\left(\mu_{1}-\mu_{2}\right)$ merupakan ragam rerata populasi 1 terhadap rerata populasi 2 , sedangkan $\left(\bar{X}_{1}-\bar{X}_{2}\right)$ adalah ragam rerata sampel 1 terhadap rerata sampel $2, N=$ banyaknya ratarata sampel, $n=$ jumlah data dalam sampel, $s_{P}$ adalah akar dari nilai keragaman gabungan $\left(s_{P}{ }^{2}\right)$, dan $F_{\alpha}$ adalah nilai kritik distribusi $F$. Nilai keragaman gabungan merupakan fungsi penjumlahan dari nilai keragaman data masing-masing stasiun $j\left(s_{j}^{2}\right)$. Nilai akar keragaman $\left(s_{P}\right)$ dapat dihitung berdasarkan Persamaan (3), sementara nilai $F_{\alpha}$ dapat diambil dari tabel distribusi $F$, dimana nilainya tergantung dari derajat bebas $d f_{1}$ dan $d f_{2}$.

$$
\begin{aligned}
& s_{P}=\sqrt{\frac{\left(n_{1}-1\right) s_{1}^{2}+\left(n_{2}-1\right) s_{2}^{2}+\ldots}{\left.n_{N}-1\right) s_{N}^{2}}} \\
& s_{j}^{2}=\frac{\sum_{i=1}^{N}\left(x_{i}-\bar{X}\right)^{2}}{N-1} \\
& d f_{1}=N-1 \\
& d f_{2}=\sum_{i=1}^{N} n-N
\end{aligned}
$$


Untuk uji perbandingan ganda dengan jumlah rata-rata sampel yang banyak, tidak terdapat ketentuan berapa jumlah rata-rata sampel yang tidak seragam untuk memutuskan bahwa hipotesis nol ditolak dan hipotesis alternatif diterima. Oleh karena hipotesis statistik dilakukan dengan menggunakan data sampel, maka kebenaran atau ketidakbenaran suatu hipotesis statistik tidak pernah diketahui dengan pasti (Boediono dan Koster, 2001).

\section{Data penelitian}

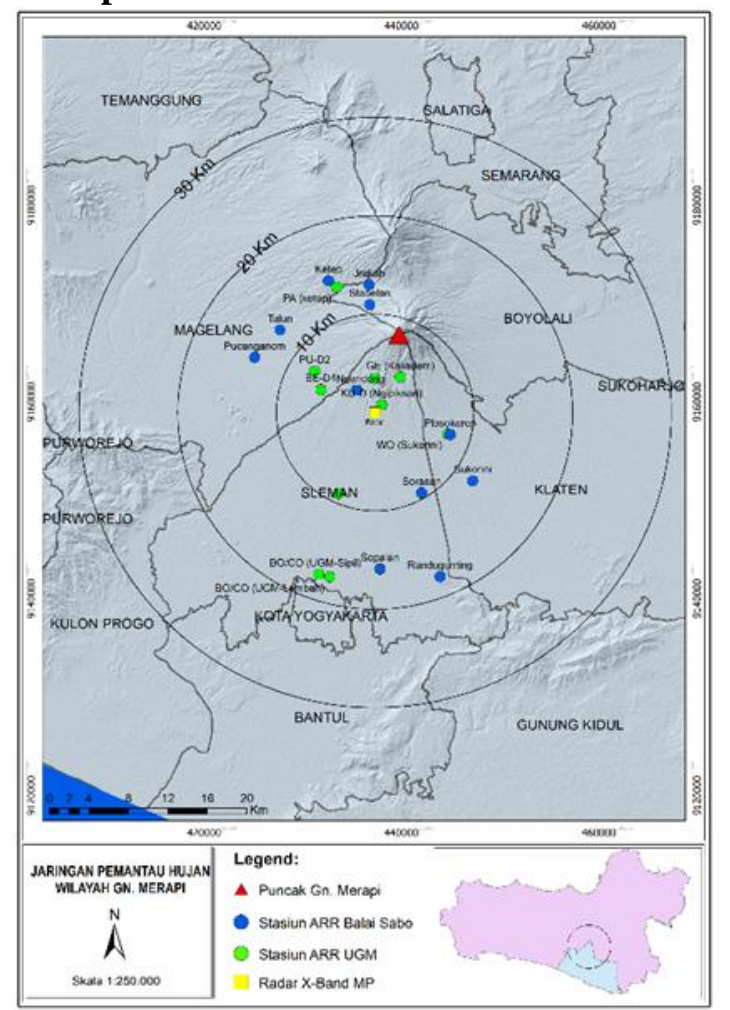

Gambar 1. Peta jaringan pemantau hujan wilayah Gunung Merapi.

Penelitian terhadap keandalan data penakar hujan otomatis dengan menggunakan uji ragam ini dilakukan terhadap 21 stasiun penakar hujan otomatis (ARR) di wilayah Gunung Merapi. Seluruh ARR merupakkan penakar hujan tipe tipping bucket yang dilengkapi dengan data logger dan modem untuk transfer data secara daring. Stasiun-stasiun ARR ini merupakan bagian dari jaringan pemantau hujan untuk mendukung sistem peringatan banjir lahar Gunung Merapi. Sebelas (11) stasiun ARR dioperasikan oleh Balai Sabo, Kementerian Pekerjaan Umum dan Perumahan Rakyak Republik Indonesia, sementara sepuluh (10) stasiun lainnya merupakan instrumen pemantau hujan milik Laboratorium Hidraulika Departemen Teknik Sipil dan
Lingkungan Universitas Gadjag Mada. Peta lokasi stasiun ARR disajikan pada Gambar 1.
ARR
Laboratorium
Hidraulika melakukan pencatatan data hujan dengan interval 2-5 menitan, sedangkan ARR Balai Sabo memiliki interval pencatatan setiap 10 menit. Dalam penelitian ini, interval hujan 10 menitan dipilih dengan pertimbangan kesetaraan agihan seluruh stasiun ARR serta keperluannya lebih lanjut untuk koreksi perkiraan hujan radar yang juga ditetapkan dengan interval 10 menitan.

Tabel 1. Nilai parameter statistik dasar uji ragam data tiap-tiap stasiun ARR

\begin{tabular}{|c|c|c|c|c|}
\hline ID & Stasiun & $\begin{array}{l}\text { Jumlah } \\
\text { data }(n)\end{array}$ & $\begin{array}{l}\text { Rata-rata } \\
(\mathrm{mm} / \mathrm{jam})\end{array}$ & $\begin{array}{c}\text { Ragam } \\
\qquad\left(s_{j}^{2}\right)\end{array}$ \\
\hline BS01 & Pucanganom & 258 & 5.72 & 58.93 \\
\hline BSO2 & Randugunting & 290 & 15.53 & 584.59 \\
\hline BS03 & Sopalan & 154 & 18.88 & 543.05 \\
\hline BS04 & Sorasan & 401 & 11.70 & 322.24 \\
\hline BS05 & Jrakah & 408 & 12.22 & 220.99 \\
\hline BS06 & Ketep & 278 & 9.69 & 156.00 \\
\hline BS07 & Ngandong & 541 & 13.20 & 363.58 \\
\hline BS08 & Plosokerep & 361 & 11.21 & 175.30 \\
\hline BS09 & Stabelan & 378 & 9.36 & 175.43 \\
\hline BS10 & Talun & 173 & 7.56 & 93.20 \\
\hline BS11 & Sukorini & 361 & 29.37 & 1843.60 \\
\hline LH01 & BE-D4 & 629 & 11.48 & 217.87 \\
\hline LH02 & BO (Turgo) & 242 & 22.43 & 526.30 \\
\hline LH03 & PA (Ketep) & 213 & 10.97 & 172.29 \\
\hline LH04 & PU-D2 & 196 & 22.14 & 937.75 \\
\hline LH05 & GE (Kaliadem) & 243 & 15.25 & 94.43 \\
\hline LH06 & $\begin{array}{l}\text { KU-D } \\
\text { (Ngipiksari) }\end{array}$ & 119 & 23.63 & 659.09 \\
\hline LH07 & WO (Sukorini) & 54 & 13.56 & 240.52 \\
\hline LH08 & $\begin{array}{l}\text { BO/CO (UGM- } \\
\text { Sipil) }\end{array}$ & 256 & 14.21 & 449.15 \\
\hline LH09 & $\begin{array}{l}\text { BO/CO (UGM- } \\
\text { Lembah) }\end{array}$ & 207 & 13.53 & 314.60 \\
\hline LH10 & BO (Donoharjo) & 177 & 13.66 & 264.89 \\
\hline
\end{tabular}

Sebanyak 5939 data dari 59 kejadian hujan pada rentang 2016 hingga 2018 di wilayah Gunung Merapi dipilih untuk diuji keandalannya. Di wilayah Gunung Merapi, hujan dengan intensitas rendah $(\leq 20 \mathrm{~mm})$ dan durasi yang panjang lebih sering terjadi dibandingkan hujan dengan intensitas yang tinggi dan durasi sesaat (Hambali, dkk., 2019). Data hujan 10-menitan yang terpilih adalah 
data kedalaman hujan yang memiliki nilai $>0$ $\mathrm{mm}$. Masing-masing stasiun memiliki jumlah kejadian hujan yang berbeda (Tabel 1), karena tidak semua kejadian hujan terdistribusi merata pada wilayah studi.

Berdasarkan Tabel 1, nilai rata-rata intensitas hujan 10 menitan seluruh stasiun ARR adalah $14.54 \mathrm{~mm} / \mathrm{jam}$. Beberapa stasiun menunjukkan nilai rata-rata intensitas hujan yang cukup mencolok dibandingkan nilai ratarata seluruh stasiun, antara lain stasiun BS01 (Pucanganom), BS10 (Talun), BS11 (Sukorini), LH02 (BO-Turgo), LH04 (PU-D2), dan LH06 (KU-D-Ngipiksari).

\section{Metode analisis}

Untuk menyatakan apakah data suatu stasiun ARR andal atau tidak untuk digunakan sebagai acuan koreksi perkiraan hujan radar, dapat dilihat berdasarkan hasil uji hipotesa. Data hujan andal apabila $H_{0}$ diterima, sementara data tidak andal apabila $H_{0}$ ditolak dan $H_{a}$ diterima. Penetapan kriteria penerimaan $H_{0}$ atau $H_{a}$ harus dilihat berdasarkan signifikansi perbedaan nilai rata-ratanya terhadap nilai rata-rata stasiun yang lain. Mempertimbangkan jumlah stasiun yang terbatas, maka ditetapkan bahwa kriteria hipotesa alternatif diterima apabila terdapat sekurang-kurangnya dua ragam populasi yang tidak sama $\left(H_{a}\right.$ : ragam populasi yang tidak sama $\geq 2$ ). Dengan kata lain, data pada suatu stasiun ARR dianggap andal apabila nilai rataratanya tidak berbeda nyata dengan nilai ratarata lebih dari satu stasiun lain.

Untuk menjawab hipotesis tersebut, langkah analisis yang dilakukan dimulai dengan menghitung nilai rata-rata $(\bar{X})$ dan ragam $\left(s_{j}^{2}\right)$ intensitas hujan 10 menitan tiaptiap stasiun ARR. Selanjutnya, menghitung variabel suku pertama ruas kanan dari Persamaan (2), yaitu selisih nilai rata-rata dari dua stasiun ARR. Nilai-selisih rata-rata ini akan dibandingkan dengan nilai kritik uji Scheffe yang dihitung berdasarkan suku kedua dan ketiga ruas kanan Persamaan (2). Apabila selisih nilai rata-rata dari dua stasiun ARR lebih besar daripada nilai kritik uji Scheffe, maka selisih rata-rata antara dua stasiun dikatakan berbeda nyata. Apabila pada satu stasiun terdapat paling sedikit dua nilai yang berbeda nyata terhadap stasiun lain, maka $H_{0}$ ditolak dan $H_{a}$ diterima.

Oleh karena uji ragam metode Scheffe ini merupakan uji ragam dua arah, dapat saja terjadi suatu stasiun yang tidak seragam mempengaruhi hasil akhir pada stasiun yang lain. Untuk itu, proses eliminasi stasiun ARR dari hasil uji Scheffe diurutkan dari stasiun yang memiliki perbedaan paling banyak terhadap stasiun yang lain. Apabila stasiunstasiun yang dinyatakan berbeda nyata dari stasiun lain telah dieliminasi, maka stasiunstasiun yang tadinya terpengaruh oleh stasiun yang datanya tidak andal menjadi mungkin dapat diterima berdasarkan $H_{0}$.

\section{HASIL DAN PEMBAHASAN}

Hasil hitungan beda rata-rata intensitas hujan 10 menitan antar stasiun ARR disajikan pada Tabel 2. Tabel 2 dapat dibaca secara horisontal maupun vertikal. Baris pertama dan kolom pertama merupakan identitas (ID) stasiun ARR. Sebagai contoh, jika dibaca ke arah horisontal, baris kedua merupakan selisih nlai rata-rata stasiun BS01 (Pucanganom) terhadap stasiun BS02 (Randugunting), BS03 (Sopalan), dan seterusnya.

Berdasarkan Tabel 2, dapat dilihat bahwa beberapa stasiun menunjukkan nilai beda rata-rata yang cukup signifikan terhadap stasiun yang lain, antara lain stasiun BS10 (Talun), BS11 (Sukorini), LH02 (BO-Turgo), LH04 (PU-D2), dan LH06 (KU-D-Ngipiksari). Perbedaan signifikan tersebut diindikasikan dari selisih nilai rata-rata yang cukup besar terhadap banyak stasiun lain. Namun demikian, selisih nilai rata-rata tersebut tidak dapat dijadikan acuan untuk menyatakan perbedaan nyata yang dimaksud. Sebagaimana telah disampaikan sebelumnya, selisih nilai rata-rata pada Tabel 2 akan dibandingkan dengan nilai kritik uji Scheffe. 
Tabel 2. Selisih nilai rata-rata intensitas hujan 10 menitan antar stasiun ARR (mm/jam)

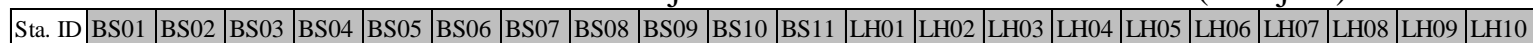
\begin{tabular}{|l|l|l|l|l|l|l|l|l|l|l|l|l|l|l|l|l|l|l|l|l|l|}
\hline BS01 & -9.81 & -13.16 & -5.98 & -6.50 & -3.97 & -7.48 & -5.49 & -3.64 & -1.84 & -23.65 & -5.76 & -16.71 & -5.25 & -16.42 & -9.53 & -17.91 & -7.84 & -8.49 & -7.81 & -7.94 \\
\hline
\end{tabular}

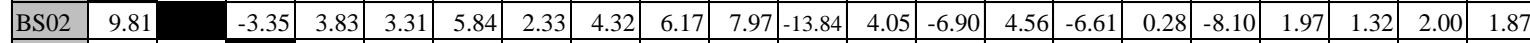

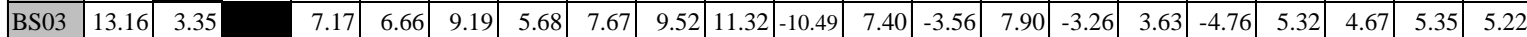
\begin{tabular}{|l|l|l|l|l|l|l|l|l|l|l|l|l|l|l|l|l|l|l|l|l|l|}
\hline BS04 & 5.98 & -3.83 & -7.17 & & -0.52 & 2.01 & -1.50 & 0.49 & 2.35 & 4.14 & -17.67 & 0.22 & -10.73 & 0.73 & -10.43 & -3.55 & -11.93 & -1.86 & -2.51 & -1.83 & -1.96 \\
\hline
\end{tabular} \begin{tabular}{|l|l|l|l|l|l|l|l|l|l|l|l|l|l|l|l|l|l|l|l|l|l|l|}
\hline BS05 & 6.50 & -3.31 & -6.66 & 0.52 & & 2.53 & -0.98 & 1.01 & 2.86 & 4.66 & -17.15 & 0.74 & -10.21 & 1.25 & -9.92 & -3.03 & -11.41 & -1.34 & -1.99 & -1.31 & -1.44 \\
\hline
\end{tabular}

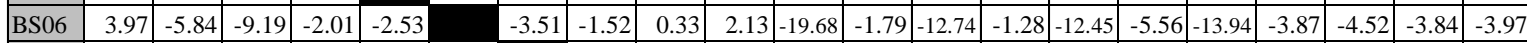
\begin{tabular}{|l|l|l|l|l|l|l|l|l|l|l|l|l|l|l|l|l|l|l|l|l|l|l|}
\hline BS07 & 7.48 & -2.33 & -5.68 & 1.50 & 0.98 & 3.51 & & 1.99 & 3.84 & 5.64 & -16.17 & 1.72 & -9.23 & 2.23 & -8.94 & -2.05 & -10.43 & -0.36 & -1.01 & -0.33 & -0.46 \\
\hline
\end{tabular} \begin{tabular}{|l|l|l|l|l|l|l|l|l|l|l|l|l|l|l|l|l|l|l|l|l|l|}
\hline BS08 & 5.49 & -4.32 & -7.67 & -0.49 & -1.01 & 1.52 & -1.99 & & 1.85 & 3.65 & -18.16 & -0.27 & -11.22 & 0.24 & -10.93 & -4.04 & -12.42 & -2.35 & -3.00 & -2.32 & -2.45 \\
\hline
\end{tabular}

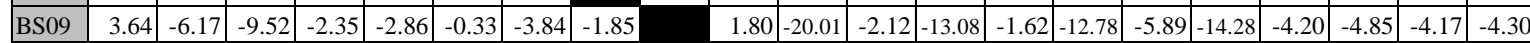
\begin{tabular}{|l|l|l|l|l|l|l|l|l|l|l|l|l|l|l|l|l|l|l|l|l|l|}
\hline BS10 & 1.84 & -7.97 & -11.32 & -4.14 & -4.66 & -2.13 & -5.64 & -3.65 & -1.80 & & -36.93 & -19.04 & -29.99 & -18.53 & -29.70 & -22.81 & -31.19 & -21.12 & -21.77 & -21.09 & -21.22 \\
\hline
\end{tabular} \begin{tabular}{|l|r|r|r|r|r|r|r|r|r|r|r|r|r|r|r|r|r|r|r|r|r|r|r|r|r|r|r|}
\hline BS11 & 23.65 & 13.84 & 10.49 & 17.67 & 17.15 & 19.68 & 16.17 & 18.16 & 20.01 & 36.93 & & 17.89 & 6.94 & 18.40 & 7.23 & 14.12 & 5.74 & 15.81 & 15.16 & 15.84 & 15.71 \\
\hline
\end{tabular} \begin{tabular}{|l|r|r|r|r|r|r|r|r|r|r|r|r|r|r|r|r|r|r|r|r|r|r|r|r|}
\hline LH01 & 5.76 & -4.05 & -7.40 & -0.22 & -0.74 & 1.79 & -1.72 & 0.27 & 2.12 & 19.04 & -17.89 & & -10.95 & 0.51 & -10.66 & -3.77 & -12.15 & -2.08 & -2.73 & -2.05 & -2.18 \\
\hline
\end{tabular} \begin{tabular}{|l|r|r|r|r|r|r|r|r|r|r|r|r|r|r|r|r|r|r|r|r|r|r|r|}
\hline LH02 & 16.71 & 6.90 & 3.56 & 10.73 & 10.21 & 12.74 & 9.23 & 11.22 & 13.08 & 29.99 & -6.94 & 10.95 & & 11.46 & 0.30 & 7.18 & -1.20 & 8.87 & 8.22 & 8.90 & 8.77 \\
\hline
\end{tabular}

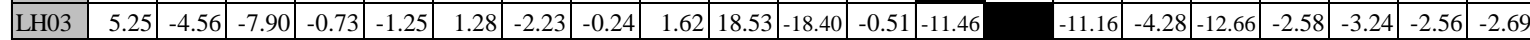
\begin{tabular}{|l|r|r|r|r|r|r|r|r|r|r|r|l|l|l|l|l|l|l|l|l|l|}
\hline LH04 & 16.42 & 6.61 & 3.26 & 10.43 & 9.92 & 12.45 & 8.94 & 10.93 & 12.78 & 29.70 & -7.23 & 10.66 & -0.30 & 11.16 & & 6.89 & -1.50 & 8.58 & 7.93 & 8.61 & 8.48 \\
\hline
\end{tabular} \begin{tabular}{|l|l|l|l|l|l|l|l|l|l|l|l|l|l|l|l|l|l|l|l|l|l|}
\hline LH05 & 9.53 & -0.28 & -3.63 & 3.55 & 3.03 & 5.56 & 2.05 & 4.04 & 5.89 & 22.81 & -14.12 & 3.77 & -7.18 & 4.28 & -6.89 & & -8.38 & 1.69 & 1.04 & 1.72 & 1.59 \\
\hline
\end{tabular} \begin{tabular}{|l|r|r|r|r|r|r|r|r|r|r|r|r|r|r|r|r|r|r|r|r|r|r|r|}
\hline LH06 & 17.91 & 8.10 & 4.76 & 11.93 & 11.41 & 13.94 & 10.43 & 12.42 & 14.28 & 31.19 & -5.74 & 12.15 & 1.20 & 12.66 & 1.50 & 8.38 & & 10.07 & 9.42 & 10.10 & 9.97 \\
\hline
\end{tabular}

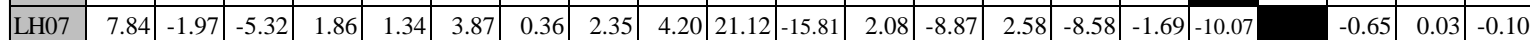

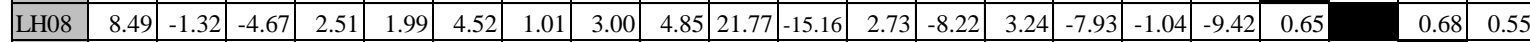

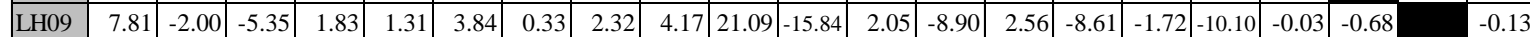
\begin{tabular}{|l|l|l|l|l|l|l|l|l|l|l|l|l|l|l|l|l|l|l|l|l|l|l|l|l|}
\hline LH10 & 7.94 & -1.87 & -5.22 & 1.96 & 1.44 & 3.97 & 0.46 & 2.45 & 4.30 & 21.22 & -15.71 & 2.18 & -8.77 & 2.69 & -8.48 & -1.59 & -9.97 & 0.10 & -0.55 & 0.13 \\
\hline
\end{tabular}

Uji Scheffe secara keseluruhan dilakukan melalui perbandingan nilai tiap-tiap sel pada Tabel 2 dengan nilai tiap-tiap sel yang sama pada Tabel 3. Berdasarkan hasil perbandingan tersebut, akan ditentukan apakah selisih nilai rata-rata antara dua stasiun ARR berbeda nyata atau tidak. Penyelesaian hitungan nilai kritik uji Scheffe membutuhkan nilai variabel $s_{P}, d f_{1}, d f_{2}$ dan $F_{\alpha}$. Contoh hitungan nilai kritik uji Scheffe diberikan untuk data stasiun BS01 dan BS02 sebagai berikut:

Jumlah rata-rata sampel $=$ jumlah stasiun $(N)=$ 21; Jumlah total data dalam sampel $\left(\sum n\right)=$ 5939; Jumlah data stasiun BS01 $\left(n_{1}\right)=258$; Jumlah data stasiun BS02 $\left(n_{2}\right)=290$; jumlah data dan nilai keragaman tiap-tiap stasiun $\left(s_{j}{ }^{2}\right)$ yang lain dapat dilihat pada Tabel 1. Dengan menggunakan Persamaan (3), didapat nilai $s_{P}=$ 19.96.

$d f_{1}=N-1=21-1=20$

$$
d f_{2}=\sum_{i=1}^{N} n-N=5939-21=5918
$$

Dengan menetapkan selang kepercayaan 95\% atau derajat nyata $(\alpha) 5 \%$, maka didapat nilai kritik distribusi $F$ untuk $F_{0.05}(20: 5918)$ sebesar 1.57. Nilai kritik uji Scheffe dihitung berdasarkan suku kedua dan ketiga ruas kanan Persamaan (2).

$$
\begin{aligned}
& \sqrt{(N-1) F_{\alpha}} s_{P} \sqrt{\frac{1}{n_{1}}+\frac{1}{n_{2}}} \\
& \sqrt{(21-1) 1.57} 19.96 \sqrt{\frac{1}{258}+\frac{1}{290}}=9.58
\end{aligned}
$$

Nilai 9.58 menunjukkan nilai kritik uji Scheffe stasiun BS01 terhadap stasiun BS02 atau sebaliknya. Hasil hitungan nilai kritik uji Scheffe untuk seluruh stasiun ARR disajikan pada Tabel 3. 
Tabel 3. Nilai kritik uji Scheffe (mm/jam)

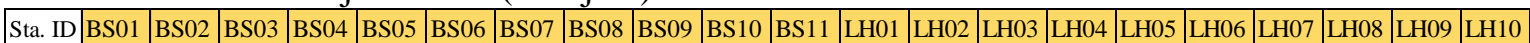

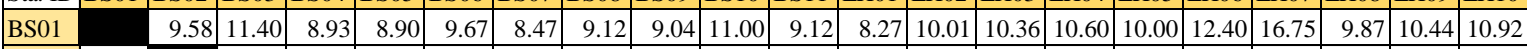
\begin{tabular}{|l|l|l|l|l|l|l|l|l|l|l|l|l|l|l|l|l|l|l|l|l|}
\hline BS02 & 9.58 & 11.16 & 8.63 & 8.60 & 9.39 & 8.14 & 8.82 & 8.74 & 10.75 & 8.82 & 7.94 & 9.74 & 10.10 & 10.35 & 9.73 & 12.18 & 16.59 & 9.60 & 10.18 & 10.67 \\
\hline
\end{tabular} \begin{tabular}{|l|r|r|r|r|r|r|r|r|r|r|r|r|r|r|r|r|r|r|r|r|r|r|r|}
\hline BS03 & 11.40 & 11.16 & & 10.61 & 10.58 & 11.24 & 10.22 & 10.77 & 10.70 & 12.40 & 10.77 & 10.06 & 11.54 & 11.84 & 12.05 & 11.53 & 13.66 & 17.70 & 11.41 & 11.91 & 12.33 \\
\hline
\end{tabular}

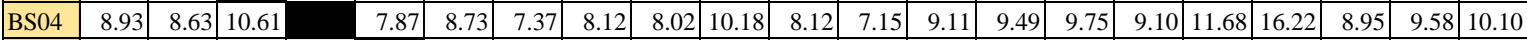

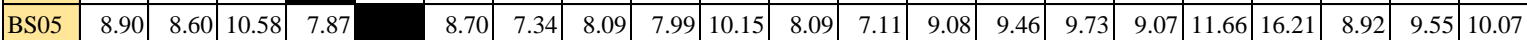

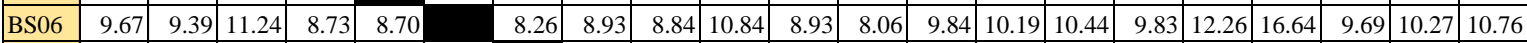

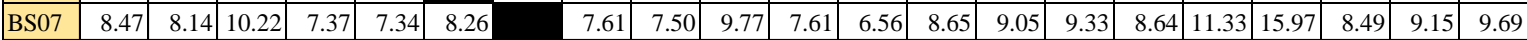

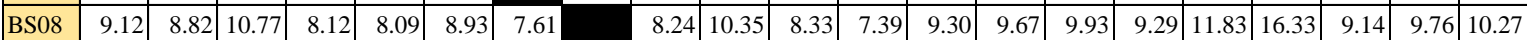

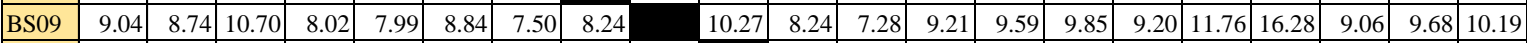

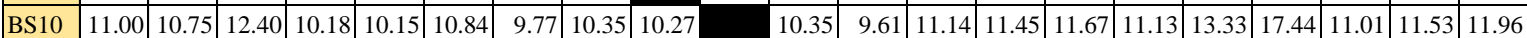
\begin{tabular}{|l|l|l|l|l|l|l|l|l|l|l|l|l|l|l|l|l|l|l|l|l|l|l|l|}
\hline BS11 & 9.12 & 8.82 & 10.77 & 8.12 & 8.09 & 8.93 & 7.61 & 8.33 & 8.24 & 10.35 & & 7.39 & 9.30 & 9.67 & 9.93 & 9.29 & 11.83 & 16.33 & 9.14 & 9.76 & 10.27 \\
\hline L & 8.27 & 7.94 & 0.06 & 7.15 & 7.11 & 8.06 & 6.56 & 7.39 & 7.28 & 9.61 & 7.39 & & 8.47 & 8.87 & 9.15 & 8.45 & 11.1 & 15.87 & 8.30 & 8.97 & 9.52 \\
\hline
\end{tabular}

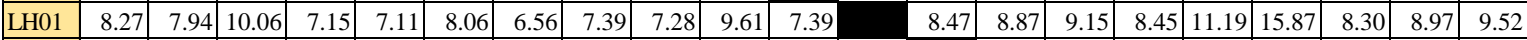

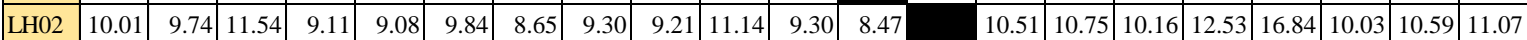

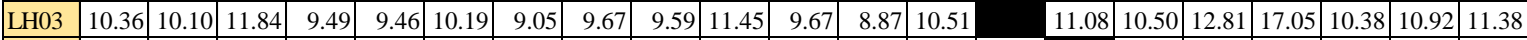

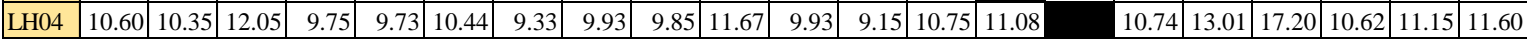

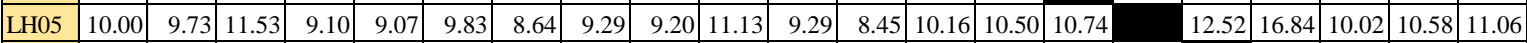
\begin{tabular}{|l|r|r|r|r|r|r|r|r|r|r|r|r|r|r|r|r|r|r|r|r|r|r|}
\hline LH06 & 12.40 & 12.18 & 13.66 & 11.68 & 11.66 & 12.26 & 11.33 & 11.83 & 11.76 & 13.33 & 11.83 & 11.19 & 12.53 & 12.81 & 13.01 & 12.52 & 18.36 & 12.42 & 12.87 & 13.27 \\
\hline
\end{tabular}

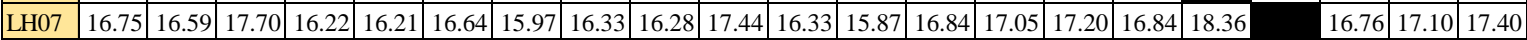

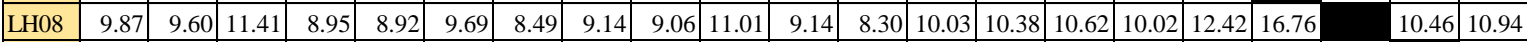

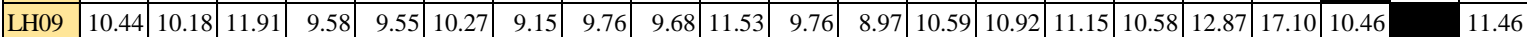
\begin{tabular}{|l|l|l|l|l|l|l|l|l|l|l|l|l|l|l|l|l|l|l|l|l|}
\hline LH10 & 10.92 & 10.67 & 12.33 & 10.10 & 10.07 & 10.76 & 9.69 & 10.27 & 10.19 & 11.96 & 10.27 & 9.52 & 11.07 & 11.38 & 11.60 & 11.06 & 13.27 & 17.40 & 10.94 & 11.46 \\
\hline
\end{tabular}

Berdasarkan perbandingan nilai tiaptiap sel yang sama pada Tabel 2 dan Tabel 3, dapat diketahui derajat perbedaan nyata antar dua nilai rata-rata. Sebagai contoh, selisih nilai rata-rata stasiun BS01 terhadap stasiun BS02 pada Tabel 2 adalah 9.81, sementara nilai kritik uji Scheffe antara stasiun BS01 dan stasiun BS02 pada Tabel 3 adalah 9.58. Oleh karena selisih nilai ratarata stasiun BS01 terhadap stasiun $\mathrm{BS} 02$ lebih besar daripada nilai kritik uji Scheffenya, maka selisih dua nilai rata-rata tersebut dikatakan berbeda nyata.

Tabel 4 merupakan rekapitulasi kesimpulan hasil uji Scheffe, dimana "N" menyatakan dua selisih nilai rata-rata tidak berbeda nyata, sedangkan "Y" menyatakan dua selisih nilai rata-rata berbeda nyata. Berdasarkan Tabel 4, terdapat tujuh stasiun ARR yang menunjukkan perbedaan nyata nilai rata-ratanya, yaitu BS01, BS10, BS11, LH01, LH02, LH04, dan LH06. Stasiun BS11 merupakan stasiun yang memiliki perbedaan nyata nilai rata-rata paling banyak terhadap stasiun lain, yaitu 11, diikuti dengan stasiun BS10, LH02, LH04, LH06, BS01, dan BS02. Dengan mengeliminasi stasiunstasiun yang memiliki perbedaan nyata yang lebih banyak secara berurutan, maka terdapat 15 stasiun ARR yang memiliki data andal untuk digunakan sebagai acuan koreksi hujan radar karena dianggap mengandung data yang tidak berbeda nyata secara signifikan. Stasiun-stasiun ARR yang dimaksud adalah Randugunting, Sopalan, Sorasan, Jrakah, Ketep, Ngandong, Plosokerep, Stabelan, BED4, PA (Ketep), GE (Kaliadem), WO (Sukorini), BO/CO (UGM-Sipil), BO/CO (UGM-Lembah), dan BO (Donoharjo).

Banyak faktor yang dapat menyebabkan data hujan yang tercatat pada satu stasiun ARR menjadi tidak andal. Pada jaringan pemantau hujan wilayah Gunung Merapi, beberapa kesalahan pencatatan data hujan diindikasi akibat kinerja tipping bucket yang nilai kalibrasinya telah berubah seiring waktu dan pemakaian. Selain itu, gangguan pada corong dan bucket oleh debu/abu dan serpihan tanaman juga menyebabkan curah hujan yang tercatat tidak sesuai dengan kejadian sesungguhnya. Meskipun demikian, pemeriksaan keandalan secara mendetail terhadap satu persatu data kejadian hujan pada tiap-tiap stasiun sulit dilakukan, mengingat karakteristik hujan di wilayah Gunung Merapi yang sangat dinamis. Selain itu, belum ditemukan metode yang tepat untuk menguji keandalan data hujan berbasis kejadian pada tiap-tiap stasiun. 
Tabel 4. Rekapitulasi hasil uji Scheffe

\begin{tabular}{|l|l|l|l|l|l|l|l|l|l|l|l|l|l|l|l|l|l|l|l|l|l|}
\hline Sta. ID & BS01 & BS02 & BS03 & BS04 & BS05 & BS06 & BS07 & BS08 & BS09 & BS10 & BS11 & LH01 & LH02 & LH03 & LH04 & LH05 & LH06 & LH07 & LH08 & LH09 & LH10 \\
\hline
\end{tabular}

\begin{tabular}{|c|c|c|c|c|c|c|c|c|c|c|c|c|c|c|c|c|c|c|c|c|c|}
\hline BS01 & & $\mathrm{Y}$ & $\mathrm{Y}$ & $\mathrm{N}$ & $\mathrm{N}$ & $\mathrm{N}$ & $\mathrm{N}$ & $\mathrm{N}$ & $\mathrm{N}$ & $\mathrm{N}$ & $\mathrm{Y}$ & $\mathrm{N}$ & $\mathrm{Y}$ & $\mathrm{N}$ & $\mathrm{Y}$ & $\mathrm{N}$ & $\mathrm{Y}$ & $\mathrm{N}$ & $\mathrm{N}$ & $\mathrm{N}$ & $\mathrm{N}$ \\
\hline BS02 & $\mathrm{Y}$ & & $\mathrm{N}$ & $\mathrm{N}$ & $\mathrm{N}$ & $\mathrm{N}$ & $\mathrm{N}$ & $\mathrm{N}$ & $\mathrm{N}$ & $\mathrm{N}$ & $\mathrm{Y}$ & $\mathrm{N}$ & $\mathrm{N}$ & $\mathrm{N}$ & $\mathrm{N}$ & $\mathrm{N}$ & $\mathrm{N}$ & $\mathrm{N}$ & $\mathrm{N}$ & $\mathrm{N}$ & $\mathrm{N}$ \\
\hline BS03 & $\mathrm{Y}$ & $\mathrm{N}$ & & $\mathrm{N}$ & $\mathrm{N}$ & $\mathrm{N}$ & $\mathrm{N}$ & $\mathrm{N}$ & $\mathrm{N}$ & $\mathrm{N}$ & $\mathrm{N}$ & $\mathrm{N}$ & $\mathrm{N}$ & $\mathrm{N}$ & $\mathrm{N}$ & $\mathrm{N}$ & $\mathrm{N}$ & $\mathrm{N}$ & $\mathrm{N}$ & $\mathrm{N}$ & $\mathrm{N}$ \\
\hline BS04 & $\mathrm{N}$ & $\mathrm{N}$ & $\mathrm{N}$ & & $\mathrm{N}$ & $\mathrm{N}$ & $\mathrm{N}$ & $\mathrm{N}$ & $\mathrm{N}$ & $\mathrm{N}$ & $\mathrm{Y}$ & $\mathrm{N}$ & $\mathrm{Y}$ & $\mathrm{N}$ & $\mathrm{Y}$ & $\mathrm{N}$ & $\mathrm{Y}$ & $\mathrm{N}$ & $\mathrm{N}$ & $\mathrm{N}$ & $\mathrm{N}$ \\
\hline BS05 & $\mathrm{N}$ & $\mathrm{N}$ & $\mathrm{N}$ & $\mathrm{N}$ & & $\mathrm{N}$ & $\mathrm{N}$ & $\mathrm{N}$ & $\mathrm{N}$ & $\mathrm{N}$ & Y & $\mathrm{N}$ & $\mathrm{Y}$ & $\mathrm{N}$ & $\mathrm{Y}$ & $\mathrm{N}$ & $\mathrm{N}$ & $\mathrm{N}$ & $\mathrm{N}$ & $\mathrm{N}$ & $\mathrm{N}$ \\
\hline BS06 & $\mathrm{N}$ & $\mathrm{N}$ & $\mathrm{N}$ & $\mathrm{N}$ & $\mathrm{N}$ & & $\mathrm{N}$ & $\mathrm{N}$ & $\mathrm{N}$ & $\mathrm{N}$ & Y & $\mathrm{N}$ & $\mathrm{Y}$ & $\mathrm{N}$ & $\mathrm{Y}$ & $\mathrm{N}$ & $\mathrm{Y}$ & $\mathrm{N}$ & $\mathrm{N}$ & $\mathrm{N}$ & $\mathrm{N}$ \\
\hline BS07 & $\mathrm{N}$ & $\mathrm{N}$ & $\mathrm{N}$ & $\mathrm{N}$ & $\mathrm{N}$ & $\mathrm{N}$ & & $\mathrm{N}$ & $\mathrm{N}$ & $\mathrm{N}$ & $\mathrm{Y}$ & $\mathrm{N}$ & $\mathrm{Y}$ & $\mathrm{N}$ & $\mathrm{N}$ & $\mathrm{N}$ & $\mathrm{N}$ & $\mathrm{N}$ & $\mathrm{N}$ & $\mathrm{N}$ & $\mathrm{N}$ \\
\hline BS08 & $\mathrm{N}$ & $\mathrm{N}$ & $\mathrm{N}$ & $\mathrm{N}$ & $\mathrm{N}$ & $\mathrm{N}$ & $\mathrm{N}$ & & $\mathrm{N}$ & $\mathrm{N}$ & $\mathrm{Y}$ & $\mathrm{N}$ & $\mathrm{Y}$ & $\mathrm{N}$ & $\mathrm{Y}$ & $\mathrm{N}$ & $\mathrm{Y}$ & $\mathrm{N}$ & $\mathrm{N}$ & $\mathrm{N}$ & $\mathrm{N}$ \\
\hline BS09 & $\mathrm{N}$ & $\mathrm{N}$ & $\mathrm{N}$ & $\mathrm{N}$ & $\mathrm{N}$ & $\mathrm{N}$ & $\mathrm{N}$ & $\mathrm{N}$ & & $\mathrm{N}$ & $\mathrm{Y}$ & $\mathrm{N}$ & $\mathrm{Y}$ & $\mathrm{N}$ & $\mathrm{Y}$ & $\mathrm{N}$ & $\mathrm{Y}$ & $\mathrm{N}$ & $\mathrm{N}$ & $\mathrm{N}$ & $\mathrm{N}$ \\
\hline BS10 & $\mathrm{N}$ & $\mathrm{N}$ & $\mathrm{N}$ & $\mathrm{N}$ & $\mathrm{N}$ & $\mathrm{N}$ & $\mathrm{N}$ & $\mathrm{N}$ & $\mathrm{N}$ & & Y & $\mathrm{Y}$ & $\mathrm{Y}$ & $\mathrm{Y}$ & $\mathrm{Y}$ & $\mathrm{Y}$ & Y & Y & $\mathrm{Y}$ & $\mathrm{Y}$ & $\mathrm{Y}$ \\
\hline BS11 & $\mathrm{Y}$ & $\mathrm{Y}$ & $\mathrm{N}$ & $\mathrm{Y}$ & Y & $\mathrm{Y}$ & $\mathrm{Y}$ & $\mathrm{Y}$ & $\mathrm{Y}$ & Y & & Y & $\mathrm{N}$ & $\mathrm{Y}$ & $\mathrm{N}$ & $\mathrm{Y}$ & $\mathrm{N}$ & $\mathrm{N}$ & $\mathrm{Y}$ & $\mathrm{Y}$ & $\mathrm{Y}$ \\
\hline LH01 & $\mathrm{N}$ & $\mathrm{N}$ & $\mathrm{N}$ & $\mathrm{N}$ & $\mathrm{N}$ & $\mathrm{N}$ & $\mathrm{N}$ & $\mathrm{N}$ & $\mathrm{N}$ & $\mathrm{Y}$ & $\mathrm{Y}$ & & $\mathrm{Y}$ & $\mathrm{N}$ & $\mathrm{Y}$ & $\mathrm{N}$ & $\mathrm{Y}$ & $\mathrm{N}$ & $\mathrm{N}$ & $\mathrm{N}$ & $\mathrm{N}$ \\
\hline LH02 & $\mathrm{Y}$ & $\mathrm{N}$ & $\mathrm{N}$ & $\mathrm{Y}$ & $\mathrm{Y}$ & $\mathrm{Y}$ & $\mathrm{Y}$ & $\mathrm{Y}$ & $\mathrm{Y}$ & $\mathrm{Y}$ & $\mathrm{N}$ & $\mathrm{Y}$ & & $\mathrm{Y}$ & $\mathrm{N}$ & $\mathrm{N}$ & $\mathrm{N}$ & $\mathrm{N}$ & $\mathrm{N}$ & $\mathrm{N}$ & $\mathrm{N}$ \\
\hline LH03 & $\mathrm{N}$ & $\mathrm{N}$ & $\mathrm{N}$ & $\mathrm{N}$ & $\mathrm{N}$ & $\mathrm{N}$ & $\mathrm{N}$ & $\mathrm{N}$ & $\mathrm{N}$ & $\mathrm{Y}$ & $\mathrm{Y}$ & $\mathrm{N}$ & $\mathrm{Y}$ & & $\mathrm{Y}$ & $\mathrm{N}$ & $\mathrm{N}$ & $\mathrm{N}$ & $\mathrm{N}$ & $\mathrm{N}$ & $\mathrm{N}$ \\
\hline LH04 & $\mathrm{Y}$ & $\mathrm{N}$ & $\mathrm{N}$ & $\mathrm{Y}$ & $\mathrm{Y}$ & $\mathrm{Y}$ & $\mathrm{N}$ & $\mathrm{Y}$ & $\mathrm{Y}$ & $\mathrm{Y}$ & $\mathrm{N}$ & $\mathrm{Y}$ & $\mathrm{N}$ & $\mathrm{Y}$ & & $\mathrm{N}$ & $\mathrm{N}$ & $\mathrm{N}$ & $\mathrm{N}$ & $\mathrm{N}$ & $\mathrm{N}$ \\
\hline LH05 & $\mathrm{N}$ & $\mathrm{N}$ & $\mathrm{N}$ & $\mathrm{N}$ & $\mathrm{N}$ & $\mathrm{N}$ & $\mathrm{N}$ & $\mathrm{N}$ & $\mathrm{N}$ & $\mathrm{Y}$ & Y & $\mathrm{N}$ & $\mathrm{N}$ & $\mathrm{N}$ & $\mathrm{N}$ & & $\mathrm{N}$ & $\mathrm{N}$ & $\mathrm{N}$ & $\mathrm{N}$ & $\mathrm{N}$ \\
\hline LH06 & $\mathrm{Y}$ & $\mathrm{N}$ & $\mathrm{N}$ & $\mathrm{Y}$ & $\mathrm{N}$ & $\mathrm{Y}$ & $\mathrm{N}$ & Y & $\mathrm{Y}$ & $\mathrm{Y}$ & $\mathrm{N}$ & $\mathrm{Y}$ & $\mathrm{N}$ & $\mathrm{N}$ & $\mathrm{N}$ & $\mathrm{N}$ & & $\mathrm{N}$ & $\mathrm{N}$ & $\mathrm{N}$ & $\mathrm{N}$ \\
\hline LH07 & $\mathrm{N}$ & $\mathrm{N}$ & $\mathrm{N}$ & $\mathrm{N}$ & $\mathrm{N}$ & $\mathrm{N}$ & $\mathrm{N}$ & $\mathrm{N}$ & $\mathrm{N}$ & $\mathrm{Y}$ & $\mathrm{N}$ & $\mathrm{N}$ & $\mathrm{N}$ & $\mathrm{N}$ & $\mathrm{N}$ & $\mathrm{N}$ & $\mathrm{N}$ & & $\mathrm{N}$ & $\mathrm{N}$ & $\mathrm{N}$ \\
\hline LH08 & $\mathrm{N}$ & $\mathrm{N}$ & $\mathrm{N}$ & $\mathrm{N}$ & $\mathrm{N}$ & $\mathrm{N}$ & $\mathrm{N}$ & $\mathrm{N}$ & $\mathrm{N}$ & $\mathrm{Y}$ & $\mathrm{Y}$ & $\mathrm{N}$ & $\mathrm{N}$ & $\mathrm{N}$ & $\mathrm{N}$ & $\mathrm{N}$ & $\mathrm{N}$ & $\mathrm{N}$ & & $\mathrm{N}$ & $\mathrm{N}$ \\
\hline LH09 & $\mathrm{N}$ & $\mathrm{N}$ & $\mathrm{N}$ & $\mathrm{N}$ & $\mathrm{N}$ & $\mathrm{N}$ & $\mathrm{N}$ & $\mathrm{N}$ & $\mathrm{N}$ & $\mathrm{Y}$ & $\mathrm{Y}$ & $\mathrm{N}$ & $\mathrm{N}$ & $\mathrm{N}$ & $\mathrm{N}$ & $\mathrm{N}$ & $\mathrm{N}$ & $\mathrm{N}$ & $\mathrm{N}$ & & $\mathrm{N}$ \\
\hline LH10 & $\mathrm{N}$ & $\mathrm{N}$ & $\mathrm{N}$ & $\mathrm{N}$ & $\mathrm{N}$ & $\mathrm{N}$ & $\mathrm{N}$ & $\mathrm{N}$ & $\mathrm{N}$ & $\mathrm{Y}$ & $\mathrm{Y}$ & $\mathrm{N}$ & $\mathrm{N}$ & $\mathrm{N}$ & $\mathrm{N}$ & $\mathrm{N}$ & $\mathrm{N}$ & $\mathrm{N}$ & $\mathrm{N}$ & $\mathrm{N}$ & \\
\hline
\end{tabular}

\section{KESIMPULAN}

Metode uji ragam Scheffe cukup sederhana dan mudah diterapkan untuk mengetahui secara efektif apakah nilai ratarata satu stasiun penakar hujan berbeda nyata dengan nilai rata-rata pada stasiun penakar hujan yang lain dalam suatu wilayah dengan karakteristik yang sama. Dengan menggunakan sistem matrik perbandingan nilai selisih rata-rata dan nilai kritik uji Scheffe, beda nyata nilai rata-rata antar stasiun dengan mudah dapat diketahui, bahkan untuk jumlah stasiun yang banyak.

Pada studi kasus data intensitas hujan 10 menitan dari 21 penakar hujan di wilayah Gunung Merapi, dapat diketahui bahwa hanya 15 stasiun ARR saja yang data hujannya andal untuk digunakan sebagai acuan koreksi perkiraan hujan radar, karena diindikasikan berasal dari populasi yang sama. Dengan kata lain, melalui uji Scheffe, stasiun-stasiun ARR yang mengandung data tidak andal dapat dengan efektif dieliminasi. Meskipun demikian, perlu ditekankan bahwa metode uji Scheffe pada studi kasus ini hanya dapat diterapkan untuk mengeliminasi stasiun ARR yang mengandung data tidak andal, bukan mengeliminasi data-data yang tidak andal pada stasiun tersebut. Untuk itu, teknik evaluasi keandalan data hujan berbasis kejadian dalam satu stasiun penakar hujan menjadi tantangan tersendiri untuk dapat ditemukan dalam studi di masa mendatang.

\section{UCAPAN TERIMA KASIH}

Ucapan terima kasih disampaikan kepada Lembaga Pengelola Dana Pendidikan (LPDP) Kementerian Keuangan Republik Indonesia, Laboratorium Hidraulika Departemen Teknik Sipil dan Lingkungan UGM, Balai Sabo Kementerian PUPR republik Indonesia, SATREPS Project for integrated study on mitigation of multimodal disasters caused by ejection of volcanic products, serta Jurusan Teknik Sipil Universitas Bangka Belitung.

\section{DAFTAR PUSTAKA}

Boediono, Koster, W., 2001. Teori dan Aplikasi Statistika dan Probabilitas. Rosda.

Burcea, S., Cheval, S., Dumitrescu, A., Antonescu, B., Bell, A., Breza, T., 2012. Comparison between radar estimations and rain gauge precipitations in the Moldavian Plateau (Romania). Environmental Engineering and Management Journal 11, 723-731.

Hambali, R., Legono, D., Jayadi, R., 2019. Correcting Radar Rainfall Estimates Based on Ground Elevation Function. Journal of the Civil Engineering Forum 5, 301-310.

Hong, Y., Gourley, J.J., 2015. Radar Hydrology: Principles, Models, and Application. CRC Press, Boca Raton. McHugh, M.L., 2011. Multiple Comparison 
Analysis Testing in ANOVA. Biochem. Medica 21, 203-209.

Muliantara, A., E.R., N.A.S., Widiartha, I.M., 2015. Perancangan Alat Ukur Ketinggian Curah Hujan Otomatis Berbasis Mikrokontroler. Jurnal Ilmu Komputer 8, 31-37.

Nystuen, J.A., Proni, J.R., Black, P.G., Wilkerson, J.C., 1996. A Comparison of Automatic Rain Gauges. Journal of Atmospheric and Oceanic Technology 13, 62-73.

Rashid, M.M., Romlay, M.R.M., Ferdaus, M.M., 2015. Development of Electronic Rain Gauge System. International Journal of Electronic and Electrical Engineering 3, 245249.

Rossa, A.M., Cenzon, G., Monai, M., 2010. Quantitative comparison of radar QPE to rain gauges for the 26 September 2007 Venice Mestre flood. Natural Hazards and Earth System Science 10, 371-377.

Sahlaoui, Z., Mordane, S., 2019. Radar Rainfall Estimation in Morocco: Quality Control and Gauge Adjustment. Hydrology 6, 1-13.

Sebastianelli, S., 2012. Quantitative Precipitation Estimates From DualPolarization Weather Radar in Lazio Region. Doctoral Thesis. Sapienza Universita Di Roma.
Strangeways, I., 2010. A History of Rain Gauges. Weather 65, 133-138.

Tauro, F., Selker, J., Giesen, N. Van De, Abrate, T., Uijlenhoet, R., Porfiri, M., Manfreda, S., Caylor, K., Moramarco, T., Benveniste, J., Ciraolo, G., Estes, L., Domeneghetti, A., Perks, M.T., Corbari, C., Rabiei, E., Ravazzani, G., Bogena, H., Harfouche, A., Brocca, L., Maltese, A., Wickert, A., Tarpanelli, A., Good, S., Manuel, J., Alcala, L., Petroselli, A., Cudennec, C., Blume, T., Hut, R., Grimaldi, S., 2018. Measurements and Observations in the XXI Century (MOXXI): Innovation and Multi- Disciplinarity to Sense the Hydrological Cycle. Hydrological Sciences Journal 63, 169-196.

Wibisono, Y., 2015. Metode Statistik. Gadjah Mada University Press, Yogyakarta.

WMO-No.8: Guide to Meteorological Instruments and Methods of Observation 2008, 2008th ed, 2010. . World Meteorological Organization, Switzerland.

Yoon, S.-S., Bae, D.-H., 2013. Optimal Rainfall Estimation by Considering Elevation in the Han River Basin, South Korea. Journal of Applied Meteorology and Climatology 52, 802-818. 